EUROPEAN TECHNOLOGY

\section{Hanging Together or Separately}

A FULL-SCALE systems analysis for Europe was called for by Dr J. Defay of the Belgian Office for Science Policy Programming when he gave the opening address to a two-day conference on European Technological Collaboration in London last week. Piecemeal approaches to European collaboration had failed, he said, and the time had come to accept that Europe could only progress by creating a single customs union, single institutions for the technologies like aircraft, nuclear power and computers and, finally, a monetary union. Surprising as it is, he said, the successes of American technology were a direct result of central planning, with public debate almost totally bypassed. But there are still ten to fifteen years in which to set up an independent Europe that will not be merely a second-hand export market for American solutions, American hardware and American vocabulary.

Dr J. B. Adains, director of the CERN $300 \mathrm{GeV}$ proton accelerator project, took the opportunity to chide the British Government for its decision to keep Britain out of the new accelerator project. "If we don't build this machine now," he said, "we shall be virtually opting out of this most basic field of research in which we have made so much progress in the sixties. What we shall lose will not be the research resultsthese will be published in the United States and the Soviet Union-it will be the adverse affect on teaching and education that will be most serious." He added that the spirit of collaboration in CERN has already been shaken by the British decision. The real nub of the problem was whether each government would select projects solely according to its own interests.

Professor B. Flowers, chairman of the Science Research Council, pointed out that it was still not too late to go ahead with the project, which now hangs delicately poised for a decision by the CERN council at the end of this year. Professor Flowers conceded, however, that some of the advocates of the $300 \mathrm{GeV}$ machine may have played their hands rather untidily early on. They now realized that the pyramid of high energy research could contain a smaller angle than had originally been suggested.

Dr Raymond Appleyard, executive secretary of the European Molecular Biology Organization, was keen that the plans for a large EMBO laboratory did not also fall on the scrap heap. It was important, he said, that the training and group advantages of a large European laboratory should not be sacrificed for the more politically inviting solution of several small laboratories situated in different countries. At present, many European laboratories had closer associations with American than with Europcan laboratories, and he thought a large EMBO laboratory would act as a focus in Europe. He saw no point in trying to compete with the United States in the hardware field, but in software there was a great opportunity. Looking to the future, he thought that the present preoccupation with basic molecular biology would soon give way to more technologically oriented research. The study of the mammatian cell was the next step, he said, and from there research would gain an increasingly technological slant. He cited some likely fruits of present research as the production of highly specific drug types, control of malignant cells and a solution of the competition between regeneration, transplant and substitution therapies.

\section{CANADIAN SCIENCE}

\section{Towards a Science Policy}

Something of a hornet's nest has been stirred up by the Canadian Senate Committee on Science Policy which is nearing the end of a marathon investigation begun in March last year. Roughly equivalent, if there were such a thing, to a British Select Committee on Science and Technology appointed by the House of Lords, the Senate Committee is expected to report before the end of the year. By then it will have sifted through 9,000 pages of evidence and the chairman, Senator Maurice Lamontagne, believes that there has never before been such a detailed review of any country's science effort. Last week members of the committee and Senator Lamontagne were in London for the final phase of the investigation of how other countries manage their scientific and technological resources. During the previous three weeks, the committee had visited seven European countries, meeting representatives from ninety-five organizations.

Hearings in Canada ended in June, and the indications are that the committee has found the control of Canadian science to be in as many hands as it is elsewhere. The committee received fifty-five briefs from Canadian government agencies, and Senator Lamontagne said that this indicated how diffuse the Canadian science effort is. It is no secret that the senator would like to see a streamlining of management of Canadian science, and one idea which has been put forward is for a Ministry of Science in overall control. But Canadian industry is also likely to come in for a good deal of criticism in the forthcoming report as the weakest sector of the Canadian scientific community. In the effort to increase Canadian expenditure on research and development from its current level of about 1.5 per cent of the GNP up to a target 2 per cent by 1972 , it is industrial research and development which is hoped to show the greatest expansion (sce Nature, 233, 766; 1969). To this end, the federal government has initiated seven major projects as a means of increasing the amount of research and development, and much discussion has centred around what kind of incentives would best stimulate industry. One problem is that much of Canadian industry is financed from the United States, and the crucial research tends to be kept in American laboratories. And Canada also has a unique problem in the need to develop the natural resources of its northern regions. It will be interesting to see what recommendations Senator Lamontagne's committee has to make.

\section{ENGLISH CHANNEL}

\section{End of Tunnel in Sight ?}

TunNex, bridge, or even dam? The debate continues over the best way of building a link across the English Channel, even though the Ministry of Transport says that any link consisting in whole or in part of a bridge has been ruled out. Later this year, the British and French Governments are expected to decide between the three international groups of companies competing 
for the job to make yet another detailed two-year study of technical, commercial and economic factors affecting the Channel Tunnel. It is intended that the study will then form the basis for final decisions on the proposed rail tunnel, which would be built by private enterprise and run by a public organization whose financial undertakings would include the remuneration of the companies concerned.

Locations for the rail terminals at the English end of the tunnel have already been discussed, after an examination in 1968 by a group based on the Ministry of Transport. Ashford in Kent was first marked out as a possible site, but now it seems that locations nearer the coast are more favoured. Three kinds of terminal would be required, the largest of which would be a ferry terminal for transferring vehicles to the trains that would take them through the 35 miles of tunnel. The other installations would be a railway passenger station and a freight yard. No decisions have been made about the final siting of any of these, but there are half a dozen sites in Kent which look promising.

The tunnel itself, which could be open in 1976 if all went well, would run from near Folkestone to a point in France near Calais and use $25 \mathrm{kV}$ overhead electrification. Ferry trains would carry up to 300 road vehicles, and would run a frequent shuttle service; other traffic would include through freight and passenger trains from centres in Britain to many continental destinations.

Alternatives to the tunnel are not likely to meet with much success now, in view of the official commitment to a rail link under the Channel, although there is always Stansted Airport to be borne in mind as an example of a last-minute change. All would depend on how far a rival suggestion could win popular support on a large scale. Devoted readers of Nature may remember a competition at the end of last year to design a dam for the Channel; another approach, advocated by a number of academics including at least one engineering professor, involves a combined bridge and tunnel, and the success of a project of this kind in Chesapeake Bay in the United States has prompted the Institution of Civil Engineers to invite General L. J. Sverdrup (chairman of the firm of consultants that designed the scheme) to give a lecture in London on September 29 about the project.

The interesting point here is the use of four artificial islands as points of interchange between sections of bridge and tunnel. Two tunnels, each over a mile long, run beneath important shipping channels and the remaining gaps are crossed by bridges. Because one of the main objections to a Channel bridge is that it would take too long to negotiate suitable agreements among the eighty or so nations whose maritime activities would be affected, this design looks at first sight attractive. It falls down, however, on cost. A study group in 1962 reported that a bridge-tunnel combination might be more than three times as expensive as the rail tunnel.

What is rather more relevant, if less exciting, is the method that the American engineers have used to build the tunnels. Concrete tubing is lowered into a trench across the sea floor which is then filled to a depth of at least five metres. This is one of the two techniques considered for the English Channel, the second being the traditional boring of holes from each end to meet in the middle. According to the Ministry of Transport, the immersed-tube illea has not been rejected, and the final decision may therefore, it seems, rest on fairly fine points.

\section{INTERNATIONAL MEETINGS More Food Not Enough}

\section{from our Botany Correspondent}

Delegates to the eleventh International Botanical Congress in Washington earlier this month joined the ranks of those who feel that the solution to world food problems can come only through population control. When the botanists' contribution to increasing food supplies was discussed, a minority of delegates felt strongly that no amount of effort would be adequate. This group left its mark on the final wording of the first resolution passed by the plenary session of the congress on September 2, to the effect that members of the congress, conscious of their responsibilities as biologists, considered that there can be no solution to the food problem unless population control is achieved. The resolution went on to urge governments to adopt appropriate policies, at the same time ensuring an adequate standard of living for their people, particularly by encouraging the increased food production which goes with proper land use.

Further mindful of their responsibilities as biologists, the delegates passed an all embracing resolution urging individuals and organizations interested in conservation to do all in their power to preserve the Earth's biosphere from the destructive influence of men. The resolution also urged governments and other organizations to support the conservation projects of the International Biological Programme and those that are within the ambit of the International Council of Scientific Unions and the International Union for Conservation of Nature and Natural Resources. The delegates evidently had no difficulty in reaching unanimous agreement on this topic. But the obvious problem with such a resolution is that it will be extremely difficult to put into effect.

A practical step may be the setting up of an environmental biology section within the International Botanical Congress. A third resolution passed on September 2 urged the planning committee for the next congress, to be held in Leningrad in 1975, to make provision for sessions devoted to the problem of the deterioration of the environment. Whether or not the new section is set up remains to be seen. The general feeling was that the organizers of the next congress should not be restricted by any resolution passed now, and so environmental biology may or may not form an official part of the proceedings in Leningrad.

\section{SCIENCE EDUCATION}

\section{Soviet Prizes and Problems}

\section{from a Correspondent}

THE opening of the new academic year has, as is customary, been hailed by the Soviet Press with reviews of the current achievements in Soviet education and plans for the immediate future. Much of the discussion has been concerned with the relationship of current 